\title{
Effect of drug therapy on circulating and synovial fluid Ig-secreting cells in rheumatoid arthritis
}

\author{
SANAD AL-BALAGHI, HÅKAN STRÖM AND ERNA MÖLLER
}

From the Department of Clinical Immunology, Huddinge Hospital, and the Division of Rheumatology, $\overrightarrow{0}$ Department of Internal Medicine, Danderyd Hospital, Karolinska Institute Medical School, Stockholm, $\overrightarrow{\vec{\omega}}$ Sweden

SUMMARY A common immunological abnormality in rheumatoid arthritis (RA) is an increased spontaneous polyclonal B cell activation. In order to study the influence of drug therapy in RA on the functional activity of B cells we enumerated spontaneous plaque-forming cells (PFC) in peripheral blood lymphocytes (PBL) and synovial fluid lymphocytes (SFL) by a reverse 인 haemolytic plaque assay. Spontaneous IgG-, IgM-, and IgA-PFC in PBL of 26 patients with $\vec{\rightarrow}$ classical erosive RA receiving either gold salts or D-penicillamine were similar to those observed $\frac{D}{2}$ in 20 healthy controls. In contrast, significantly higher numbers of IgG- and IgA-PFC, but not IgM-PFC, were found in PBL of nine patients with classical erosive RA receiving non-steroidal $₫$ anti-inflammatory drugs (NSAID) alone. Furthermore, spontaneous PFC in SFL from $16^{\circ}$ consecutive patients with RA receiving second-line drugs, as well as 17 patients with other forms of arthritis (non-RA) were generally low and significantly less than those observed in $20 \mathrm{RA}$ patients on NSAID alone. Moreover, a wide individual variation in PFC, especially in relation to the IgG class, was recorded in the synovial lymphocytes. These studies imply that treatment with $\stackrel{\circ}{\varnothing}$ second-line drugs is associated with normalisation of $\mathrm{B}$ cell activity in RA patients, and that the effect can be detected at the cellular level both in blood and synovial fluid.

Key words: antibody formation, gold thiomalate, D-penicillamine, non-steroidal anti-inflammatory drugs.

In rheumatoid arthritis there is ample evidence of increased activity in the antibody forming cell system. This was exemplified by increased spontaneous B cell proliferation, ${ }^{12}$ increased background Ig-secreting cells, ${ }^{34}$ and polyclonal Ig secretion including autoantibodies. ${ }^{5-7}$ Although the cause of $B$ cell hyper-reactivity is still unknown, viral and bacterial products with polyclonal $B$ cell activating (PBA) properties have been implicated. ${ }^{8} \mathrm{~A}$ very high proportion of activated $B$ cells in the rheumatoid synovium secrete rheumatoid factor (RF), which has been postulated to play an important role in the pathogenesis of rheumatoid injury. ${ }^{910}$

Treatment with gold salts and penicillamine has long been shown to improve both the clinical and laboratory findings in patients with RA. ${ }^{11-13} \mathrm{~A}$ tendency for normalisation in the serum level of

Accepted for publication 26 September 1984.

Correspondence to Dr Sanad Al-Balaghi, Department of Clinical Immunology, Huddinge University Hospital, S-141 86 Huddinge, Sweden. immunoglobulins, as well as other disease character- -3 istics, such as RF and immune complexes, has beeno found during effective treatment with gold salts and penicillamine. ${ }^{14-18}$.

By the protein A plaque assay, which detects? Ig-secreting cells, we have previously demonstratedo the presence of markedly increased numbers of spontaneous Ig-secreting cells in blood and synoviakr fluids of patients with active seropositive RA whon were not receiving gold, penicillamine, corticoster- $-\mathrm{W}_{\mathrm{N}}$ oid, or cytostatic drugs. ${ }^{3}$ The present paper is ano extension of our previous observations with the aim of studying the effect of NSAID, compared with gold salts and D-penicillamine, on circulating andof synovial fluid Ig-secreting cells in RA patients.

\section{Materials and methods}

PATIENTS AND CONTROLS

Eighty-eight patients and 20 healthy nursing and medical staff from the Division of Rheumatology, 
Department of Internal Medicine, Danderyd Hospital, Stockholm, were studied.

The first group included 35 patients selected on the basis of their clinical findings and therapy, in whom numbers of circulating PFC were analysed and compared with 20 healthy controls. All patients fulfilled the American Rheumatism Association criteria for classical $\mathrm{RA}^{19}$ and had typical erosive radiographic abnormalities. Thirty-two patients had positive tests for RF on at least two occasions during their illness, whereas the other three had only one positive test. Nine patients were receiving NSAID, 13 were on gold sodium thiomalate (Myocrisin) and another 13 on D-penicillamine (Dista Products). In order to ensure compatibility of the patients and in view of the reported differences between classical erosive and non-erosive $\mathrm{RA}^{20-22}$ only patients with classical erosive seropositive RA were included in this group. As expected, several had negative tests for RF at the time of this study (Table 1) following a period of drug therapy. ${ }^{14} 15$ Further clinical and laboratory characteristics are presented in Table 1. Control subjects included 10 females and 10 males with an average age of 39.1 years (SD 3.4, range 20-63).

The second group included 53 consecutive patients with various forms of arthritis, in whom numbers of spontaneous PFC were analysed simultaneously in blood and synovial fluid. These included: (1) 20 patients with RA (12 classical and eight definite) who were receiving NSAID alone; (2) 16 patients with RA (seven classical and nine definite) who were receiving second-line drugs; and (3) 17 patients with non-RA (14 on NSAID and three on less than $7.5 \mathrm{mg} /$ day prednisolone). The clinical diagnosis, treatment, and other features of the patients included in this group are summarised in Table 2.

\section{SYNOVIAL FLUID PREPARATION}

All samples were collected aseptically in heparinised tubes ready for transport, which usually took about one hour. The fluid was immediately mixed with 10 $\mathrm{mg} / \mathrm{l}$ hyaluronidase (Sigma Chemical Co., St Louis, Mo, USA) at $37^{\circ} \mathrm{C}$ for $45 \mathrm{~min}$.

\section{CELL ISOLATION}

Mononuclear cells were isolated from heparinised venous blood or synovial fluid by centrifugation on a Ficoll-Isopaque (Nyegaard, Oslo) gradient. ${ }^{23}$ The cells recovered at the interphase were removed, washed four times with Hanks's balanced salt solution (HBSS), and resuspended at 0.8-1.2 $\times 10^{9}$ cells/l viable cells, as judged by the trypan blue exclusion test. Cell suspensions were always kept on ice until used.

\section{ASSAYFOR PLAQUE-FORMING CELLS}

Ig-secreting cells in lymphocyte suspensions were enumerated by a haemolysis-in-gel technique, ${ }^{24}$ as modified by Gronowicz et al. ${ }^{25}$ with protein Acoupled sheep erythrocytes as target cells. Plaques were developed with a monovalent IgG fraction of rabbit antihuman Ig specific for $\gamma, \mu$, or $\alpha$-chains

Table 1 Clinical and laboratory characteristics of 35 patients with classical erosive rheumatoid arthritis in whom circulating PFC were determined

\begin{tabular}{|c|c|c|c|}
\hline \multirow[t]{2}{*}{ Parameter } & \multicolumn{3}{|l|}{ Patient group } \\
\hline & Gold & D-Penicillamine & $N S A I D$ \\
\hline Number of patients & 13 & 13 & 9 \\
\hline Female:male & $4: 9$ & $9: 4$ & $5: 4$ \\
\hline Age (years) & $54 \cdot 3 \pm 3 \cdot 3^{*}(40-71)+$ & $60 \cdot 9 \pm 2 \cdot 4(43-70)$ & $67 \cdot 0 \pm 2 \cdot 4(44-76)$ \\
\hline Disease duration (years) & $5 \cdot 1 \pm 0.9(1-13)$ & $14 \cdot 5 \pm 2 \cdot 6(3-34)$ & $7 \cdot 0 \pm 1 \cdot 8(2-14)$ \\
\hline Drug: dose & $94 \pm 20(10-200) \mathrm{mg} / \mathrm{month}$ & $548 \pm 66(250-1000) \mathrm{mg} /$ day & $\mathrm{NE} \ddagger$ \\
\hline duration (months) & $18 \cdot 8 \pm 7 \cdot 1 \quad(2-94)$ & $67 \cdot 5 \pm 7 \cdot 3(9-84)$ & $\mathrm{NE}$ \\
\hline Extra-articular manifestations & 3 & 1 & 2 \\
\hline$R F \geqslant 1 / 40 \S$ & 11 & 6 & 7 \\
\hline$A N A \geqslant 1 / 25$ & 2 & 3 & 2 \\
\hline $\mathrm{ESR} \geqslant 28 \mathrm{~mm} / \mathrm{h}$ & 6 & 1 & 9 \\
\hline Serum IgG $(g / l)$ & $11 \cdot 49 \pm 0 \cdot 94$ & $11 \cdot 91 \pm 0.73$ & $14 \cdot 30 \pm 1 \cdot 13$ \\
\hline Serum IgM (g/l) & $1 \cdot 12 \pm 0 \cdot 19$ & $1 \cdot 12 \pm 0 \cdot 17$ & $1 \cdot 14 \pm 0 \cdot 27$ \\
\hline Serum IgA $(g / 1)$ & $1 \cdot 87 \pm 0 \cdot 23$ & $1 \cdot 89 \pm 0 \cdot 20$ & $1.98 \pm 0.32$ \\
\hline P-haptoglobin $(\mathrm{g} / \mathrm{l})$ & $2 \cdot 00 \pm 0 \cdot 30$ & $1 \cdot 61 \pm 0 \cdot 11$ & $2 \cdot 08 \pm 0 \cdot 28$ \\
\hline Orosomucoid (g/l) & $0.68 \pm 0.08$ & $0 \cdot 50 \pm 0 \cdot 02$ & $0.72 \pm 0.08$ \\
\hline
\end{tabular}

*Mean \pm SEM. +Range. $¥$ Not evaluated. $\$ A t$ the time of sampling.

ANA = antinuclear antibodies.

Normal values: serum IgG, 6.2-15 g/l; serum IgM, 0.40-2.75 g/l: serum IgA, 0.8-4.0 g/l; P-haptoglobin, 0.20-1.40 g/l; orosomucoid, $0.25-0.65 \mathrm{~g} / \mathrm{l}$. 
Table 2 Major characteristics of 53 consecutive patients with rheumatoid and non-rheumatoid arthritides, in whom circulating as well as synovial fluid PFC were analysed simultaneously

\begin{tabular}{|c|c|c|c|c|c|c|}
\hline Diagnosis & $n$ & Age (yr) & Sex & $\begin{array}{l}R F \\
\geqslant 1 / 40\end{array}$ & $\begin{array}{l}E S R \\
\geqslant 28\end{array}$ & Treatment \\
\hline RA & 20 & $59 \cdot 7 \pm 3 \cdot 2 *$ & 12F. $8 \mathrm{M}$ & 11 & 18 & NSAID \\
\hline RA & 7 & $61 \cdot 9 \pm 4 \cdot 2$ & $5 \mathrm{~F}, 2 \mathrm{M}$ & 2 & 5 & Penicillamine \\
\hline RA & 2 & $61 \cdot 5 \pm 3 \cdot 5$ & $1 \mathrm{~F}, 1 \mathrm{M}$ & 1 & 1 & Gold \\
\hline RA & 3 & $66 \cdot 0 \pm 4 \cdot 5$ & $3 \mathrm{~F}$ & 2 & 3 & Prednisolone \\
\hline Gout & 4 & $49 \cdot 5 \pm 9 \cdot 1$ & $3 \mathrm{~F}, 1 \mathrm{M}$ & 0 & 1 & NSAID \\
\hline Pelvospondylitis & 1 & 37 & $1 \mathrm{M}$ & 0 & 1 & Prednisolone \\
\hline $\begin{array}{l}\text { Juvenile recurrent } \\
\text { polyarthritis }\end{array}$ & 3 & $20 \cdot 0 \pm 2 \cdot 7$ & $2 \mathrm{~F} .1 \mathrm{M}$ & 0 & 3 & $\begin{array}{ll}2 & \text { Prednisolone } \\
1 & \text { NSAID }\end{array}$ \\
\hline Reactive arthritis & 3 & $30 \cdot(0 \pm 6 \cdot 0$ & $1 F, 2 M$ & 0 & 0 & NSAID \\
\hline Enteroarthritis & 1 & 62 & $1 F$ & 0 & 0 & NSAID \\
\hline Seronegative oligoarthritis & 5 & $38 \cdot 6 \pm 9 \cdot 5$ & $4 \mathrm{~F}, 1 \mathrm{M}$ & 0 & 2 & NSAID \\
\hline
\end{tabular}

*Mean \pm SEM.

$\mathrm{ESR}=$ erythrocyte sedimentation rate

(DAKO Immunoglobulins Ltd, Copenhagen, Denmark) diluted 1:30. The detailed procedure has been described previously. ${ }^{3}$

\section{STATISTICAL ANALYSIS}

Student's $t$ test was used for comparing means between groups. Since spontaneous PFC in synovial fluids were not normally distributed, mean values of the natural logarithms of the PFC numbers were used. Probability values ( $p$ values) were determined in two-tailed tests. When two independent groups had similar variance a pooled variance estimate of $t$ was used, otherwise a separate variance estimate of $t$ with an estimated number of degrees of freedom was used to test whether or not the means of the groups differed. Correlation was analysed by Pearson's product-moment correlation coefficients.

\section{Results}

EFFECT OF DRUG THERAPY ON SPONTANEOUS PFC IN RA BLOOD: COMPARISON WITH NORMAL CONTROLS

Spontaneous IgG-, IgM-, and IgA-PFC wereo enumerated in PBL isolated from 20 healthy con-trols and 35 patients with classical erosive RA whoo were receiving either gold salts, D-penicillamine, or NSAID alone. The major characteristics of the patient groups are given in Table 1 . The averageo numbers (mean \pm SEM) and the pattern of distribution of different Ig classes of the patient and control groups are presented in Table 3 and Fig. 1. It can be seen that patients receiving either gold salts or D-penicillamine had numbers and distribution of spontaneous PFC similar to those found in healthy controls ( $p>0.05$ for all tested Ig classes). Con-i

Table 3 Effect of drug therapy on circulating PFC (mean \pm SEM) in rheumatoid arthritis. Comparison with healthy controls. The $p$ values between cifferent groups are given for each Ig class

\begin{tabular}{|c|c|c|c|c|c|}
\hline \multirow[t]{2}{*}{ Patient } & \multicolumn{5}{|c|}{$P F C($ mean $\pm S E M) / 10^{6}$ viable cells } \\
\hline & $n$ & $\lg G$ & $\lg M$ & $\lg A$ & Total \\
\hline 1. RA+NSAID & 9 & $1018 \pm 210$ & $296 \pm 45$ & $1961 \pm 340$ & $3275 \pm 452$ \\
\hline 2. RA + gold & 13 & $294 \pm 76$ & $148 \pm 51$ & $624 \pm 128$ & $1066 \pm 206$ \\
\hline 3. $\mathbf{R A}+$ penicillamine & 13 & $325 \pm 115$ & $241 \pm 62$ & $1102 \pm 218$ & $1668 \pm 302$ \\
\hline 4. Normal controls & 20 & $218 \pm 29$ & $166 \pm 49$ & $990 \pm 131$ & $1374 \pm 167$ \\
\hline$p$ value & & & & & \\
\hline $1 v 2$ & & $<0.01$ & $\mathrm{NS}^{*}$ & $<0.01$ & $<0 \cdot 001$ \\
\hline $1 v 3$ & & $<0.01$ & NS & $<0.05$ & $<0 \cdot 01$ \\
\hline $2 v 3$ & & NS & NS & NS & NS \\
\hline $4 v 1$ & & $<0.01$ & NS & $<0.05$ & $<0 \cdot 01$ \\
\hline $4 \vee 2$ & & NS & NS & NS & NS \\
\hline $4 v 3$ & & NS & NS & NS & NS \\
\hline
\end{tabular}




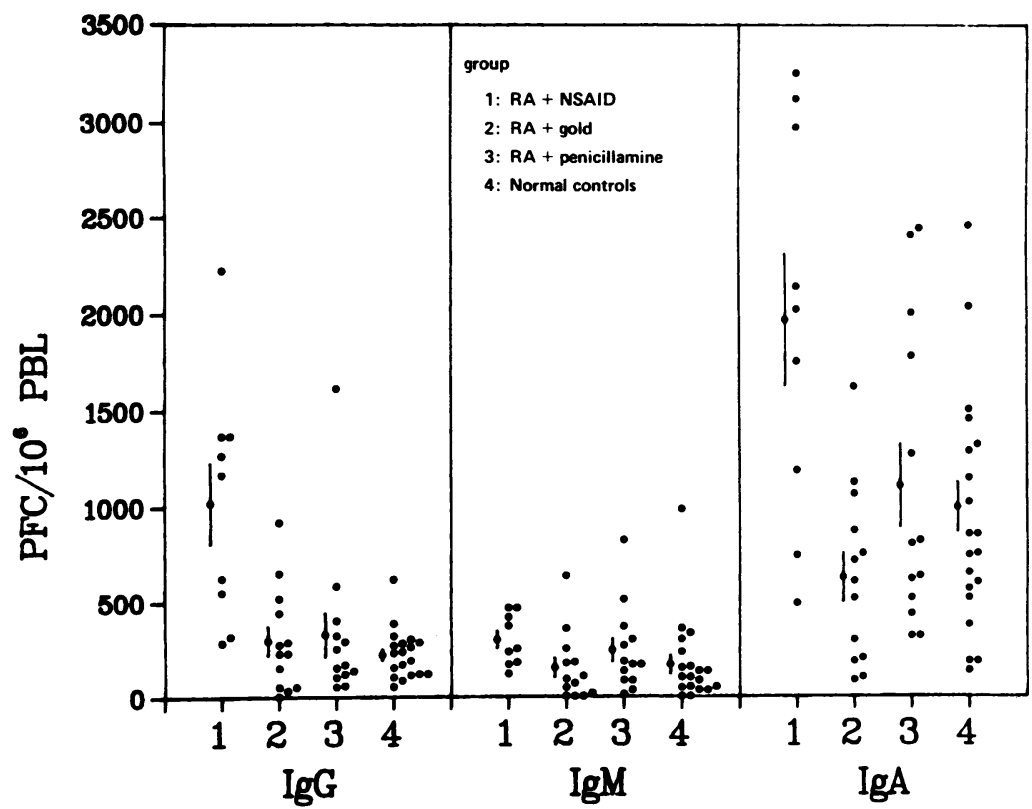

Fig. 1 Distribution of circulating IgG-, IgM-, and IgA-PFC in 20 healthy controls and $35 R A$ patients receiving either gold salts, D-penicillamine, or NSAID alone. The means and the standarderrors of the means are indicated for each group. The p values between different groups are given in Table 3 . versely, patients receiving NSAID alone had significantly more PFC than normal controls $(\mathrm{p}<0.01)$ and patients treated with either gold $(p<0.001)$ or D-penicillamine $(p<0.01)$. These differences were significant for IgG- and IgA-PFC but did not reach a significant level for IgM-PFC. There was no significant difference in PFC numbers between groups on gold salts and D-penicillamine. Thus treatment with gold salts and D-penicillamine, but not NSAID alone, is associated with normalisation of the numbers of Ig-secreting cells in RA blood.

Analysis of the data (Pearson's product-moment correlation coefficients) showed that there was a significant correlation between the total numbers of spontaneous PFC and ESR ( $r=0 \cdot 40, p=0 \cdot 02)$. The correlation was significant for IgG-PFC $(r=0.46$, $p=0.006$ ), did not reach a significant level for IgA-PFC $(r=0.30, p=0.08)$, and was not significant for IgM-PFC $(r=0 \cdot 14, p=0 \cdot 42)$. It should be pointed out that the mean levels ( \pm SEM) of ESR were significantly higher among patients receiving NSAID alone $(57.7 \pm 7.6)$ than patients treated with either gold $(32.8 \pm 7 \cdot 6, \mathrm{p}=0.04)$ or penicillamine $(19 \cdot 8 \pm 3 \cdot 1, p=0 \cdot 001)$. In the present study no significant correlation was found between the numbers of spontaneous PFC and age, sex, disease duration, extra-articular manifestations, serum levels of Ig, RF titres, P-haptoglobin, or orosomucoid.
EFFECT OF DRUG THERAPY ON SPONTANEOUS PFC IN RA SYNOVIAL FLUID: COMPARISON WITH NON-RA

In earlier studies SFL from untreated patients with RA were found to contain high numbers of spontaneous PFC. ${ }^{3}$ In the present study SFL from three groups of patients have been compared: (1) RA patients receiving NSAID alone; (2) RA patients treated with second-line drugs (gold, Dpenicillamine, corticosteroid, or chloroquine); and (3) non-RA patients. Further details are given in Table 2. As shown in Table 4, a significantly higher number of spontaneous PFC was found in RA patients receiving NSAID alone compared with those treated with second-line drugs $(p<0.01)$. Furthermore, spontaneous PFC in the non-RA synovial fluids were generally low and significantly lower than those obtained from RA patients receiving NSAID alone $(p<0 \cdot 01)$. There was no significant difference in PFC numbers between non-RA patients and RA patients on second-line drugs. IgG was the predominant Ig-class in all synovial fluids tested (Table 4). Fig. 2 shows that spontaneous PFC in synovial fluids from all patients with non-RA and RA patients treated with second-line drugs lie within a range $\leq 100-3817 / 10^{\circ} \mathrm{SFL}$. A similar range of PFC was also observed in 12 of the 20 RA patients receiving NSAID alone. In contrast, eight RA patients on NSAID alone had $4950-50625 \mathrm{PFC} / 10^{6} \mathrm{SFL}$. 
Table 4 Effect of drug therapy on synovial fluid PFC (mean $\pm S E M$ ) in rheumatoid arthritis. Comparison with non-rheumatoid arthritis. The $p$ values between different groups are given for each Ig class

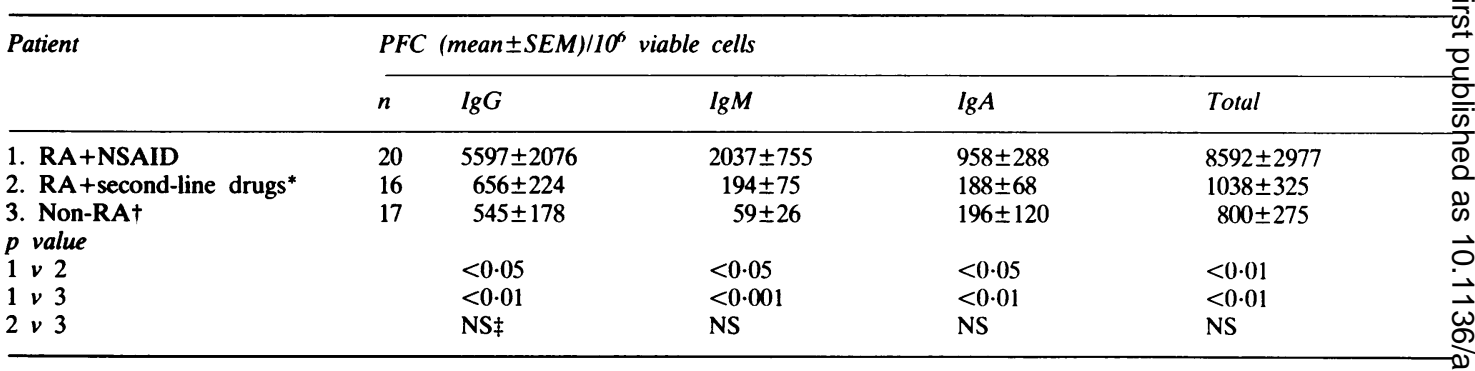

*Two gold; seven D-penicillamine; three prednisolone; and four choloroquine. †Fourteen NSAID and three prednisolone. ¥Not significant.

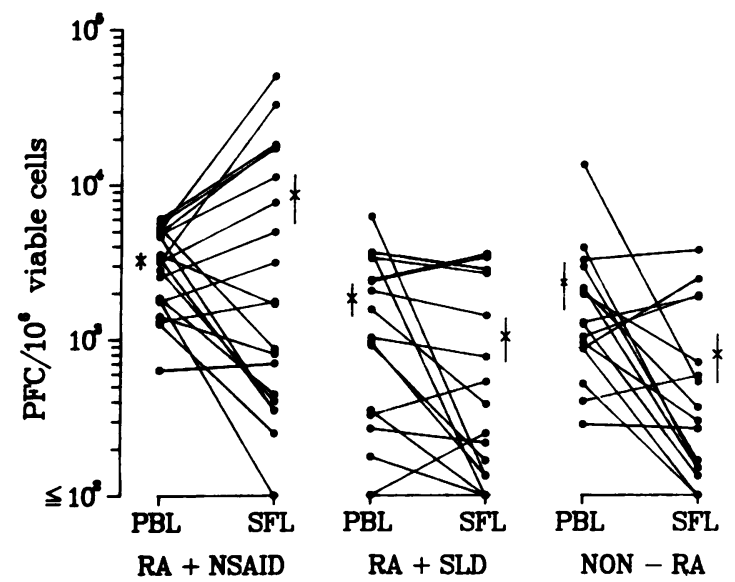

Fig. 2 Spontaneous PFC $(\operatorname{Ig} G+\operatorname{Ig} M+\operatorname{IgA})$ measured simultaneously in blood and synovial fluid lymphocytes isolated from 53 consecutive patients with rheumatoid and non-rheumatoid arthritis. Each line represents one patient. The means and the standard errors of the means are indicated for each group. Note: Spontaneous PFC in PBL of one patient from the non-RA group were not determined.

When data obtained from synovial fluids were compared with those obtained simultaneously from blood, comparable numbers or, surprisingly, much fewer PFC were found in SFL than in PBL for all patients with non-RA, for RA patients treated with second-line drugs, and for 12 of the 20 RA patients receiving NSAID alone (Fig. 2). In contrast, eight RA patients on NSAID had two- to 10 -fold more PFC in SFL than PBL indicating local production of Ig in the rheumatoid synovium.

Correlation of PFC in synovial fluid to various clinical and laboratory parameters indicated that it was not related to age, sex, disease duration, erosive lesions, RF titres, P-haptoglobin, or orosomucoid. However, a slight but significant correlation be- tween IgM- and IgG-PFC and the occurrence of extra-articular manifestations was found $(r=0.33$ 은 $p=0.01$ for $\operatorname{IgM} ; r=0.30, p=0.03$ for $\operatorname{IgG} ; r=0.18$, $\mathrm{p}=0.21$ for $\operatorname{IgA})$. Although synovial fluid $\mathrm{PFC} / 10$ 응 cells were not correlated with ESR $(r=0.21$, $\mathrm{p}=0 \cdot 14)$, spontaneous PFC in the PBL isolated from $\overrightarrow{0}$ the same patients were significantly correlated with the ESR levels $(r=0.42, p=0.002)$. Furthermore spontaneous PFC in synovial fluids were positivelyo correlated with serum levels of IgM $(r=0.42$ 를 $\mathrm{p}=0.004)$ and $\operatorname{IgG}(\mathrm{r}=0.35, \mathrm{p}=0.01)$ but not $\operatorname{Ig} \mathrm{A}_{\mathrm{O}}^{\mathrm{O}}$ $(r=0 \cdot 19, p=0 \cdot 21)$ antibodies.

\section{Discussion}

The plaque assay techniques have been widely used in recent years for the study of immunoglobulin? secretion in diseases associated with $B$ cell abnor malities such as $\mathrm{RA}^{34}$ systemic lupus erythematosus, ${ }^{2627}$ and multiple sclerosis. ${ }^{28}$ This method provides information about the functiona state of the B cells within a few hours of theis collection and, therefore, should be more reliable than determination of cumulative Ig levels in serump and joint fluid which are influenced by the rate of $I$ t catabolism and excretion. ${ }^{29}$ Thus we used the protein A plaque assay to evaluate the effect of drugr therapy in RA on the capacity of blood and synoviah fluid B lymphocytes to secrete Ig spontaneously

Our data indicated normal numbers and distribu $-{ }_{-}^{\omega}$ tion of circulating Ig-secreting cells in RA patients treated with gold salts or D-penicillamine. A expected, significantly higher numbers of spon taneous Ig-secreting cells, particularly those secret:ing IgG and IgA antibodies, were found in PBL of patients receiving NSAID alone. These results indicated that treatment with gold salts and $D \frac{?}{\mathrm{Q}}$ penicillamine, but not NSAID alone, is associated with normalisation of $B$ cell activity in the RA blood. Using a similar technique, Pardo and 
Levinson ${ }^{30}$ have also demonstrated the presence of normal numbers of circulating PFC in RA patients receiving gold therapy. However, the effect of D-penicillamine therapy on active antibody producing cells has not previously been described. Previous reports about the effect of treatment with gold and penicillamine on serum levels of Ig have presented variable results: some investigators found no effect on serum Ig levels, ${ }^{31}$ while others demonstrated a significant reduction in all major Ig classes $(G, M$, and A). ${ }^{1732}$ Furthermore, a selective effect on certain Ig classes has also been reported, though this is variable. ${ }^{1+16} 33$

The functional activity of lymphocytes isolated from synovial fluids is thought to reflect the inflammatory process in the affected joint. Recent studies with immunohistochemical staining techniques have demonstrated a special relationship between different cell populations infiltrating the rheumatoid synovial membranes, which could ultimately lead to the activation of B lymphocytes. ${ }^{34} 35$ Therefore it is not surprising to find a high proportion of synovial fluid B lymphocytes to be activated to form Ig-secreting cells. In the present report this was particularly pronounced in eight RA patients on NSAID, where $0 \cdot 5-5 \%$ of the total synovial cells were actively engaged in antibody secretion. Among these patients two- to 10 -fold more PFC were found in SFL than in PBL, indicating local production of Ig in the rheumatoid synovium. Such high numbers of synovial fluid PFC were not found in any of our RA patients receiving second-line drugs or patients with other forms of arthritis such as gout, pelvospondylitis, juvenile recurrent arthritis, reactive arthritis, enteroarthritis, and seronegative oligoarthritis. A high rate of Ig secretion by rheumatoid synovial cells was originally described by Smiley et al. ${ }^{36}$ and later confirmed by other investigators. ${ }^{3437}$ It should be noted that there was a considerable overlap in synovial fluid PFC between the RA patients on NSAID and the other two groups of patients (Fig. 2) and, therefore, these differences are quantitative rather than qualitative. Furthermore, the data do not necessarily link the high synovial fluid PFC to diagnosis but rather to a state of local inflammation.

We have also noticed a wide individual variation in the number of SFL spontaneously secreting Ig (range $\leqslant 0.01-5 \%$ ) (Fig. 2). Similar variations in PFC numbers (range $0 \cdot 20-2 \cdot 76 \%$ ) have been reported in mononuclear cells eluted from 17 rheumatoid synovial tissues. ${ }^{4}$ Though we do not have an immediate explanation for this phenomenon, it is tempting to relate it to the presence of transient severe synovitis with subsequent release of helper factors triggering a higher proportion of $B$ cells to
Effect of drug therapy on Ig-secreting cells

secrete Ig. This assumption is supported by our recent demonstration of a helper factor with $T$ cell-replacing activity in the synovial fluid of many, but not all, RA patients. ${ }^{38}$ Subsequent studies have demonstrated that helper activities in synovial fluids were induced by active molecules distinct from materials that preferentially bind to the staphylococcal protein $\mathrm{A}$, such as IgG-immune complexes, and therefore are probably produced by activated $\mathrm{T}$ cells in the rheumatoid synovium. ${ }^{39}$

Though PFC of different Ig classes were found in SFL, more than $60 \%$ were IgG-secreting cells. This was true whether the patients had rheumatoid or other forms of arthritis and whether small or high numbers of PFC were recorded. Thus a predominance of IgG-secreting cells seems to be a special characteristic of synovial fluid B lymphocytes. A predominance of IgG antibody in the rheumatoid synovial space has been previously reported at the cellular level, ${ }^{34}$ as well as in synovial fluids and supernatants of cultured cells. ${ }^{36} 37$ The majority of IgG-containing plasma cells in the rheumatoid synovial membranes synthesise IgG-RF. ${ }^{y}$

The numbers of circulating PFC, particularly the IgG-PFC, were found to be significantly correlated with the ESR, which is in agreement with other reports. ${ }^{33}{ }^{40}$ However, we could not find a significant correlation between synovial fluid total PFC/ $10^{6}$ and ESR levels. Instead, increased numbers of synovial fluid PFC were correlated significantly with the occurrence of extra-articular manifestations, which might reflect the severity of the disease process in general.

To summarise, our data are consistent with the concept that B cells are spontaneously activated in RA patients. In addition, treatment with gold salts and D-penicillamine was found to be associated with low numbers of circulating as well as synovial fluid Ig-secreting cells. Though we have not studied the mechanism by which gold salts and D-penicillamine cause a fall in the numbers of Ig-secreting cells, our data provide an indirect clue that both drugs act on the cellular component of the immune system, either directly on B cells or indirectly via $\mathrm{T}$ cells or macrophages. Indeed, Lipsky, ${ }^{41}$ in an in-vitro study, has demonstrated that D-penicillamine in the presence of copper ions had a selective inhibitory action on helper $T$ cells but no direct effect on $B$ lymphocytes.

We thank Dr O Strandberg and Dr E Szanto for allowing us to study patients under their care. Dr B Nilsson for expert help with statistical analysis of the data, Ms Inaam Kadhem for excellent technical assistance, and Ms Anita Löfgren for typing the manuscript. This work was supported by the Swedish Medical Research Council, the Swedish Association for Rheumatism, and the King Gustaf V 80-Year Foundation. 


\section{References}

1 Carter S D, Bacon P A, Hall N D. Characterisation of activated lymphocytes in the peripheral blood of patients with rheumatoid arthritis. Ann Rheum Dis 1981; 40: 293-8.

2 Al-Balaghi S, Ström H, Möller E. Spontaneous DNA synthesis in rheumatoid arthritis: evidence of enhanced circulating non-T-cell proliferation. Scand J Immunol 1983; 17: 521-30.

3 Al-Balaghi S, Ström H, Möller E. High incidence of spontaneous Ig-producing lymphocytes in peripheral blood and synovial fluid of patients with active seropositive rheumatoid arthritis. Scand J Immunol 1982; 16: 69-76.

4 Egeland T, Lea T, Mellbye O J, Pahle J A, Ottesen T, Natvig J B. Quantitation of cells secreting immunoglobulins after elution from rheumatoid synovial tissue. Scand J Immunol 1982; 16: 413-9.

5 Veys E M, Claessens H E. Serum levels of IgG, IgM, and IgA in rheumatoid arthritis. Ann Rheum Dis 1968; 27: 431-40.

6 Kalliomäki J L, Halonen P. Salmi A. Virus antibodies in serum and synovial fluid of patients with rheumatoid arthritis and other connective tissue diseases. Ann Rheum Dis 1975; 34: 43-8.

7 Panush R S, Bianco N E, Schur P H. Serum and synovial fluid IgG, IgA and IgM antigammaglobulins in rheumatoid arthritis. Arthritis Rheum 1971; 14: 737-47.

8 Möller E, Ström H, Al-Balaghi S. Role of polyclonal activation in specific immune responses. Relevance for findings of antibody activity in various diseases (editorial). Scand $J$ Immunol 1980; 12: 177-82.

9 Munthe E, Natvig J B. Immunoglobulin classes, subclasses and complexes of IgG rheumatoid factor in rheumatoid plasma cells. Clin Exp Immunol 1972; 12: 55-70.

10 Egeland T, Lea T, Saari G, Mellbye O J, Natvig J B. Quantitation of cells secreting rheumatoid factor of IgG, IgA and IgM class after elution from rheumatoid synovial tissue. Arthritis Rheum 1982; 25: 1445-50.

11 Empire Rheumatism Council. Gold therapy in rheumatoid arthritis. Report of a multicentre controlled trial. Ann Rheum Dis 1960; 19: 95-119.

12 Empire Rheumatism Council. Gold therapy in rheumatoid arthritis. Final report of a multicentre controlled trial. Ann Rheum Dis 1961; 20: 315-34.

13 Multicentre Trial Group. Controlled trial of D-penicillamine in severe rheumatoid arthritis. Lancet 1973; i: 275-80.

14 Bluestone R, Goldberg L S. Effect of D-penicillamine on serum immunoglobulins and rheumatoid factor. Ann Rheum Dis 1973; 32: $50-2$.

15 Gottlieb N L, Kiem I M, Penneys N S, Schultz D R. The influence of chrysotherapy on serum protein and immunoglobulin levels, rheumatoid factor, and antiepithelial antibody titers. J Lab Clin Med 1975; 86: 962-72.

16 Mohammed I, Barraclough D, Holborow E J, Ansell B M. Effect of penicillamine therapy on circulating immune complexes in rheumatoid arthritis. Ann Rheum Dis 1976; 35: 458-62.

17 Lorber A, Simon T, Leeb J, Peter A, Wilcox S. Chrysotherapy. Suppression of immunoglobulin synthesis. Arthritis Rheum 1978; 21: 785-91.

18 Highton J, Panayi G S, Shepherd P, Faith A, Griffin J, Gibson $T$. Fall in immune complex levels during gold treatment of rheumatoid arthritis. Ann Rheum Dis 1981; 40: 575-9.

19 Ropes M W, Bennett G A, Cobb S. Diagnostic criteria for rheumatoid arthritis. Ann Rheum Dis 1959; 18: 49-53.

20 Lawrence J S, Bennett P H. Benign polyarthritis. Ann Rheum Dis 1960; 19: 20-30.
21 O'Sullivan J B, Cathcart E S. The prevalence of rheumatoid arthritis. Follow up evaluation of the effect of criteria on rates: in Sudbury, Massachusetts. Ann Intern Med 1972; 76: 573-7.

22 Gran J T, Husby G, Thorsby E. HLA antigens in palindromic rheumatism, nonerosive rheumatoid arthritis and classical rheumatoid arthritis. J Rheumatol 1984; 11: 136-40.

23 Böyum A. Separation of leucocytes from blood and bone $\overline{\bar{C}}$ marrow. Scand J Clin Lab Invest 1968; 21: 77-89.

24 Jerne N K. Nordin A A. Plaque formation in agar by single antibody-producing cells. Science 1963; 140: 405.

25 Gronowicz E Coutinho A. Melchers F A. Plaque assay for all cells secreting Ig of a given type or class. Eur J Immunol 1976; 6: 588-90.

26 Budman D R, Merchant E B, Steinberg A D, et al. Increased spontaneous activity of antibody-forming cells in the peripheral blood of patients with active SLE. Arthritis Rheum 1977; 20:ð̄ 829-33.

27 Fauci A S, Moutsopoulos H M. Polyclonally triggered B cells in the peripheral blood and bone marrow of normal individuals. ${ }^{+}$ and in patients with systemic lupus erythematosus and primary Sjögren's syndrome. Arthritis Rheum 1981; 24: 577-84.

28 Henriksson A, Kam-Hansen S, Andersson R. Immunoglobulin-응 producing cells in CSF and blood from patients with multiple sclerosis and other inflammatory neurological diseases enumerated by protein-A plaque assay. J Neuroimmunol 1981; 1:O 299-309.

29 Spiegelberg H L. Biological activities of immunoglobulins of different classes and subclasses. Adv Immunol 1974; 19: 259-94..

30 Pardo I, Levinson A I. Circulating immunoglobulin-secreting cells in rheumatoid arthritis. Clin Immunol Immunopathol 1983; 29: 29-34.

31 Mouridsen H T, Baerentsen O, Rossing N, Jensen K B. Lack of effect of gold therapy on abnormal IgG and IgM metabolism in rheumatoid arthritis. Arthritis Rheum 1974; 17: 391-6.

32 Norberg R, Wollheim F A. Gedda P O. Circulating protein市 complexes in D-penicillamine therapy of rheumatoid arthritis. Acta Med Scand 1980; 208: 393-96.

33 Mbuyi-Muamba J M, Dequeker J, Stevens E. D-Penicillamine in rheumatoid arthritis: laboratory findings with particular reference to complement and immunoglobulins. Acta Clin Belg음 1982; 37: 299-306

34 Janossy G, Panayi G, Duke O, Bofill M, Poulter L W. ָِ Goldstein G. Rheumatoid arthritis: a disease of T-lymphocyte/e macrophage immunoregulation. Lancet 1981; ii: 839-42.

35 Klareskog L, Forsum U, Wigren A, Wigzell H. Relationships between HLA-DR-expressing cells and $T$ lymphocytes of different subsets in rheumatoid synovial tissue. Scand J Im-O munol 1982; 15: 501-7.

36 Smiley J D, Sachs C, Ziff M. In vitro synthesis of immunoglobu-윽 lin by rheumatoid synovial membrane. J Clin Invest 1968; 47: 624-32.

37 Sliwinski A J, Zvaifler $\mathrm{N}$ J. In vitro synthesis of IgG by rheumatoid synovium. J Lab Clin Med 1970; 76: 304-10. N

38 Al-Balaghi S, Ström H, Möller E. B cell differentiation factor in synovial fluid of patients with rheumatoid arthritis. Immunol $N$ Rev 1984; 78: 7-23.

39 Al-Balaghi S, Ström H, Möller E. Demonstration of a helper $\omega^{\omega}$ factor(s) with T cell-replacing activity in synovial fluid. Scand Immunol in press.

40 Claman H N, Merrill D. Serum immunoglobulins in rheumatoid arthritis. J Lab Clin Med 1966; 67: 850-4.

41 Lipsky P E. Modulation of human antibody production in vitro by D-penicillamine and $\mathrm{CuSO}_{4}$ : inhibition of helper $\mathrm{T}_{\text {cell }} \mathrm{O}$ function. J Rheumatol [Suppl] 1981; 7: 69-73. 